\title{
Konsepsual Model Bagi Mengukur Kualiti Perkhidmatan Perpustakaan Akademik
}

Che Azlan Taib

School of Technology Management and Logistic, Colleh of Business, Universiti Utara Malaysia,06010, Sintok, Kedah DA

*Corresponding author: c.azlan@uum.edu.my

\begin{abstract}
The Ninth Malaysia Plan (RMK-9) is the second phase of a national mission to achieve Vision 2020. The Eleventh Malaysia Plan (RMK-11), 2016-2020, is the latest five-year development plan towards realizing Vision 2020. One of the core the main is to increase knowledge and innovation and nurture first class mentality among Malaysians. Higher Education Institutions (HEIs) have a big responsibility to realize this vision. Thus, learning assessment instruments analyzed by Asif and Searcy should be improved to make it more comprehensive and relevant to current needs. For this purpose, an empirical study was conducted in which the data accessed across multiple groups of library user's background from 5 HEIs (private and public) in the north of Peninsular Malaysia. This study involved 381 respondents as the sample. The reliability tests through 3 criteria displayed the internal consistencies of the seven factors were satisfactorily $(\alpha=0.70)$ : Coefficient Alpha (CA), Corrected Item-Total Correlation (CITC) and Alpha if Item Deleted (IID). It shows all constructs have to comply with three criteria, namely CA, CITC and the IID. Meanwhile for the content validity views of experts was conducted. All comments have been improved before final questionnaire distributed. As a conclusion, the result indicated that the model was highly goodness fit for measuring library services, and all dimensional constructs supported the proposed theoretical model.
\end{abstract}

Keywords: Quality model, library services, Higher Education Institution (HEI), library performance.

\begin{abstract}
Abstrak
Rancangan Malaysia Kesembilan (RMK-9) merupakan fasa kedua misi nasional ke arah mencapai Wawasan 2020. Manakala Rancangan Malaysia Kesebelas (RMKe-11), 2016-2020, merupakan rancangan pembangunan lima tahun terakhir ke arah merealisasikan matlamat Wawasan 2020. Salah satu daripada teras utamanya adalah meningkatkan pengetahuan dan inovasi serta memupuk minda kelas pertama di kalangan rakyat Malaysia. Institusi Pengajian Tinggi (IPT) mempunyai tanggungjawab besar bagi mrealisasikan hasrat tersebut. Justeru, instrumen penilaian IPT yang dianalisa oleh Asif dan Searcy perlu ditambahbaik supaya lebih komprehensif dan relevan dengan keperluan semasa. Bagi tujuan itu satu kajian empirikal telah dijalankan di mana data dikumpul daripada 5 buah IPT (swasta dan awam) di Utara Semenanjung Malaysia. Pengumpulan data melalui kaedah soal selidik telah melibatkan tiga ratus lapan puluh satu (381) responden yang merangkumi 46 soalan daripada 7 kerangka dimensi kualiti perkhidmatan perpustakaan. Ujian kobolehpercayaan melalui kaedah konsisten dalaman digunakan bagi mengesahkan instrumen kajian berdasarkan 3 kriteria iaitu Coefficient Alpha (CA), Corrected Item-Total Correlation (CiTC) dan Alpha If Item Deleted (AiID). Semua dimensi iaitu perkhidmatan MUDAH DIAKSES, BERSESUAIAN, SEDIA DIGUNAKAN, BERKESAN, CEKAP, BOLEH DIPERCAYAI dan KESAHAN mempunyai nilai alpha melebihi 0.70. Ini menunjukkan semua konstruk telah mematuhi 3 kriteria yang ditetapkan iaitu CA, CiTC dan AiID. Bagi tujuan kesahan kandungan, kaedah menyoal pengamal, pertimbangan dan pandangan pakar telah dilakukan. Semua komen-komen untuk ditambahbaik telah dilakukan. Justeru, berdasarkan ujian kebolehpercayaan dan kesahan kandungan, instrumen yang dibentuk mempunyai nilai kebolehpercayaan yang baik dan sesuai dimasukkan dalam konstruk pencapaian prestasi IPT.
\end{abstract}

Kata Kunci: Model kualiti, perkhidmatan perpustakaan, institut pengajian tinggi (ipt), pencapaian perpustakaan.

(C) 2017 Penerbit UTM Press. All rights reserved

\subsection{PENGENALAN}

Kecemerlangan sistem pendidikan mencerminkan kemajuan sesebuah negara. Negara-negara seperti Jepun, Korea, Norway dan Amerika Syarikat maju kerana sistem pendidikan mereka baik. Sistem pendidikan cemerlang menyumbang kepada taraf hidup rakyat yang baik kerana pendidikan merupakan kayu ukur utama dalam kualiti hidup manusia. Justeru amat tepat apa yang dinyatakan Moris (2007) bahawa tujuan utama penubuhan Institusi Pengajian Tinggi (IPT) adalah untuk melahirkan sumber tenaga manusia yang mahir dan berkelayakan sesuai dengan keperluan negara. Sehubungan itu, misi transformasi Malaysia sebagai sebuah negara maju perlu kepada sistem pendidikan yang kukuh, mantap dan berkesan.

Perkara ini sekaligus menunjukkan perkembangan sistem pendidikan tinggi perlu disokong dengan aspek institusi dan governan yang mantap supaya IPT terus berkualiti dan mempunyai daya saing (Md. Zhahir and Imran 2006). Ini kerana IPT dinilai berdasarkan majunya institusi dalam aspek pengajaran, penyelidikan, penerbitan dan perundingan. Begitu jugalah kualiti pendidikan tinggi adalah berkaitan dengan aspek pemantapan dan kerelevenan program pengajian, persekitaran akademik yang menggalak dan memberangsangkan serta pengurusan institusi yang berkesan. Justeru, sokongan perpustakaan dalam penyediaan sumber rujukan amat penting kerana perpustakaan diiktiraf sebagai pendokong kepada program pembelajaran, pengajian dan penyelidikan bagi melahirkan masyarakat yang berilmu di samping merealisasikan Pelan Strategik Pengajian Tinggi Negara (Mustapa 2007). 
Perpustakaan juga suatu yang unik dari segi kemudahan fizikal, kemudahan teknikal, sikap dan kompetensi kakitangan berbanding lain-lain sektor perkhidmatan (Ashok Kumar Sahu 2006), malahan perpustakaan juga dikenalpasti sebagai sumber kepada pengurusan pengetahuan (Walford 2004). Menurut Adnan Ali (2006), perpustakaan sentiasa memainkan peranan penting dalam proses pengajaran, pembelajaran dan penyelidikan. Di Malaysia perpustakaan wujud bukan hanya untuk memenuhi keperluan Dasar Negara bagi Perpustakaan dan Perkhidmatan Maklumat ((KPT) 2002), malahan peranannya penting dalam konteks Kod Amalan Jaminan Kualiti IPT Awam serta merupakan salah satu daripada kriteria penentuan penarafan universiti bertaraf dunia.

Dalam era ini kesedaran dan kepentingan pendidikan di kalangan rakyat Malaysia adalah tinggi. Bilangan pelajar yang memasuki pengajian tinggi sentiasa meningkat. Di mana sehingga tahun 2013 terdapat lebih daripada 1,156,293 bilangan enrolmen pelajar di IPT (Kementerian Pendidikan Malaysia 2015). Justeru, ukur tara ataupun benchmarking merupakan komponen penting bagi membolehkan IPT meningkatkan kualiti dan prestasi proses dengan cekap dan berkesan (Imran and Md. Zhahir 2006). Menurut mereka lagi, ukur tara IPT memerlukan piawaian, dan piawaian yang dibangunkan mesti memenuhi aspek piawai akademik, peluang pembelajaran dan piawaian kebertangungjawaban institusi sebagai badan menganugerah ijazah. Ukur tara ini perlu disatukan dengan proses jaminan kualiti menyeluruh (Imran and Md. Zhahir 2006).

\subsection{OBJEKTIF KAJIAN}

Berdasarkan isu-isu kualiti di IPT, kecekapan dan keberkesanan organisasi perlu diukur secara menyeluruh. Ianya bermula dengan pengukuran input, proses dan output. Sehubungan itu perkhidmatan perpustakaan perlu diukur bagi pelengkap kepada pengukuran pencapaian sesebuah IPT kerana perpustakaan adalah sebahagian daripada IPT. ISO 11620 menggariskan beberapa penentu bagi mengukur pencapaian perpustakaan. Namun kaedah pengukuran perkhidmatan perpustakaan masih berdasarkan model yang lama seperti model SERVQUAL, SERPERF, LibQUAL dan sebagainya. Namun kaedah-kaedah pengukuran tersebut agak rumit dan sukar untuk dilaksanakan. Justeru, objektif utama kajian adalah membentuk model baharu pengukuran perkhidmatan perpustakaan dalam konteks kepuasan pelanggan bagi digabungkan dalam pengukuran pencapaian IPT.

\subsection{ULASAN BACAAN}

Dalam sejarah tamadun manusia, perpustakaan yang dikelaskan kepada beberapa kategori merupakan tempat simpanan dan sebaran khazanah hasil pemikiran manusia yang dijelmakan dalam pelbagai bentuk. Perpustakaan berperanan sebagai perkhidmatan sokongan dalam proses pengajaran dan pembelajaran. Apabila penyelidikan merupakan peranan utama IPT, maka peranan perpustakaan secara tradisional telah bertukar (Singh 2007). Perpustakaan juga dianggap sebagai jantung kepada sesebuah universiti (Lawrence 2000) dan di antara objektif utama perpustakaan akademik adalah memberi perkhidmatan bagi mendukung cita-cita atau matlamat pengajian tinggi di mana maklumat berkaitan penyelidikan, rencana teknikal atau maklumat lain yang penting dan berkualiti disusun rapi untuk faedah pengguna. Kualiti ini telah ditafsir dalam pelbagai kaedah, dalam konteks pendidikan, kualiti meliputi ciri-ciri profesionalisme, penekanan kepada pelanggan, pembaikan berterusan, kaizen, perubahan dalam budaya, rakan-rakan sekerja sebagai pelanggan, lebih mendekati pelanggan, pemasaran dalaman dan upside- down (Taylor 1995).

Secara khusus bagi sesebuah perpustakaan, Zaiton dan rakan-rakan (1998) mendapati maksud kualiti perlu diketahui daripada empat perspektif utama iaitu (i) mudah untuk mengakses koleksi perpustakaan (ii) perkhidmatan yang cepat, cekap, dan bersopan, (iii) memenuhi kehendak atau keperluan pengguna dan (iv) kemudahan dan persekitaran yang kondusif. Totterdell, Gill dan Hornsey (2005) menyatakan bagi setiap perkhidmatan perpustakaan, kualiti boleh dibahagikan kepada dua asas utama iaitu (i) kualiti dan komitmen kakitangan dan (ii) sokongan dan sumber-sumber yang disediakan. Dalam hal ini, perbincangan mengenai kualiti tidak dapat diasingkan daripada kaitannya dengan kualiti perkhidmatan. Kualiti perkhidmatan adalah output perkhidmatan yang bersifat intangible dan heterogenous iaitu tidak boleh dibilang, diukur, diperiksa, diuji atau diverifikasi serta tidak boleh disimpan (Fitzgerald, Johnston et al. 1993). Justeru, amat sukar diterjemahkan dan kesukaran ini meningkat disebabkan oleh ciri subjektif perkhidmatan itu sendiri (Jay, Connie et al. 2001) di mana pelbagai faktor seperti sosio-demografi, kumpulan kebudayaan, kehendak dan keperluan serta pengalaman perkhidmatan yang lepas mempengaruhi kualiti perkhidmatan.

Nitecki (1996) menyatakan kualiti perkhidmatan perpustakaan adalah jumlah sebenar perbezaan di antara jangkaan dengan persepsi pelanggan iaitu berdasarkan terma yang diasaskan oleh Parasuraman dan rakan-rakan (1985). Sekiranya jangkaan tinggi, kualiti perkhidmatan yang ditawarkan juga mestilah tinggi dan definisi ini telah menjadi rujukan utama dalam kebanyakan kajian. Cronin dan Taylor (1992), Gronross (1984) serta Parasuraman dan rakan-rakan (1985) menyatakan kualiti perkhidmatan terdiri daripada pelbagai dimensi. Namun tiada persetujuan umum bagi menentukan dimensi kualiti perkhidmatan (Brady and Cronin 2001). Sebagai contoh Tser-yieth (1997) menyatakan pencapaian perpustakaan universiti adalah pelbagai dan secara tradisional ianya berkaitan dengan input seperti kakitangan, koleksi buku, kapasiti tempat duduk dan sebagainya.

Baroudi dan Orilowski (1988) pula berpendapat di antara ciri-ciri yang digunakan untuk mengukur pencapaian perpustakaan termasuklah maklumat yang diterima tepat, lengkap, terkini, padat, berkaitan dan boleh dipercayai berbanding dengan jangkaan ataupun piawaian yang ditetapkan. Tom (1992) menyenaraikan contoh-contoh pengukuran pencapaian perpustakaan seperti jarak perpustakaan dengan tempat tinggal pengguna, buku sedia ada dan masa kakitangan profesional ada di meja perkhidmatan; masa tindakan diambil, seperti peratusan maklumat diminta dipenuhi, peratusan pangkalan data dicari dipenuhi, peratusan bilangan pinjaman antara perpustakaan dipenuhi selepas dua minggu dan selepas tiga minggu; dan pengukuran liputan koleksi iaitu peratusan jurnal dan monograf yang dirujuk oleh fakulti bagi subjek tertentu, nisbah buku berbanding bidang dengan permohonan, dan pengukuran stok yang berkaitan iaitu purata tahunan penggunaan setiap bahan.

Secara spesifik bagi kes perpustakaan penyelidik bersetuju dengan pandangan Hu (2001) bahawa penilaian pencapaian perpustakaan adalah berdasarkan falsafah apa-apa kaedah yang mudah-ubah yang boleh digunakan bagi menilai perkhidmatan dan aktiviti perpustakaan. Oleh itu bentuk dan kaedah pengukuran pencapaian adalah pelbagai. Pencapaian perpustakaan juga seringkali diukur berdasarkan pencapaian output seperti berapa banyak soalan rujukan dapat dijawab (Lancaster 1993). Nitecki (1995) dan Landrum (1999) pula menyatakan SERVQUAL boleh digunakan bagi mengukur pencapaian perpustakaan. Roslah dan Zainab (2007) pula menggunakan model SERVPERF dan Perkin (2004) dan Bruce (2003) menggunakan model LibQUAL+ . 
Piawaian ISO 11620 (1998(a)) menggariskan 29 penentu-penentu pengukuran pencapaian perpustakaan. Martensen dan Gronholdt (2003) pula menyenaraikan lima dimensi iaitu dari segi sumber-sumber dalam bentuk elektronik, status bahan bercetak, lain-lain perkhidmatan di perpustakaan, bantuan teknikal, keadaan persekitaran, dan tingkahlaku kakitangan perpustakaan. Nancy, Beth dan Charles (1990) menyatakan terdapat empat konstruk pengukuran iaitu kepuasan pelanggan; ketersediaan dan kegunaan bahan; kemudahan dan penggunaan perpustakaan serta perkhidmatan maklumat. Dalam konteks kepuasan pelanggan secara khusus, Bamigboye (2007) menyenaraikan elemenelemen buku siap-sedia digunakan, status pembekalan bahan bersiri, bahan-bahan koleksi rujukan, kecekapan kakitangan di bahagian rujukan, kakitangan perpustakaan sedia membantu, kemudahan infrastruktur, tempoh masa pinjaman bahan perpustakaan dan keadaan suasana dalam perpustakaan.

Menurut Young (2001) di samping ISO 11620:1998 di antara rujukan utama bagi mengukur pencapaian perpustakaan ialah Equinox (Library Performance Measurement and Quality Management System) dan McClure/Bertot IMLS 2000 Statistics and Performance Measures for Public Library Networked Service. Menurut Poll (2001), penentu-penentu pencapaian adalah nisbah pembaca yang menggunakan perkhidmatan elektronik; nisbah pembaca yang menggunakan perkhidmatan pencarian maklumat jarak jauh; nisbah peruntukan perbelanjaan yang digunakan untuk membeli sumber media; nisbah peruntukan perbelanjaan yang dibayar untuk kakitangan bagi penyediaan perkhidmatan elektronik dan media; dan nisbah peruntukan perbelanjaan yang digunakan untuk teknologi maklumat dan komunikasi. American Library Association (2000) menetapkan pengukuran pencapaian perpustakaan termasuklah koleksi perkhidmatan elektronik, rangkaian internet yang bebas dan penggunaan komunikasi elektronik yang disediakan perpustakaan bagi pengguna jarak jauh.

Brophy (2002) menerbitkan empat belas piawaian penentu pencapaian perpustakaan elektronik iaitu peratusan ahli perustakaan yang dimasukkan dalam julat perkhidmatan elektronik, bilangan masa setiap ahli mengakses perkhidmatan elektronik perpustakaan, bilangan masa setiap ahli mengakses perkhidmatan elektronik perpustakaan daripada jarak jauh, jumlah bilangan dokumen dan lain-lain bahan yang diakses semasa ahli menggunakan perkhidmatan elektronik perpustakaan, jumlah wang yang dibelanjakan untuk setiap database elektronik, jumlah wang yang dibelanjakan untuk setiap dokumen atau lain-lain item diakses secara elektronik, peratusan permintaan pertukaran sumbersumber bahan elektronik, purata penggunaan terminal komputer, jumlah masa setiap pengguna menerima perkhidmatan terminal komputer, peratusan kegagalan mengakses perkhidmatan elektronik, peratusan jumlah perbelanjaan yang digunakan untuk membayar perkhidmatan elektronik, jumlah bilangan setiap pengguna menghadiri latihan perkhidmatan elektronik, bilangan kakitangan perpustakaan yang menghadiri latihan berkaitan pembangunan, pengurusan dan pembacaan perkhidmatan elektronik dan tahap kepuasan pengguna terhadap perkhidmatan elektronik.

Sementara itu bagi pengukuran sesebuah IPT, analisis komprehensif terhadap kajian-kajian terdahulu oleh Asif dan Searcy (2014) mengklompok pencapaian kepada 4 kategori iaitu penyelidikan, pengajaran, perkhidmatan dan kewangan. Kategori, indikator dan sumber rujukan oleh mereka dirigkaskan seperti di dalam Jadual 1 hingga 4 di bawah. Berdasarkan rumusan mereka, sumber utama yang menyumbang kepada kategori percapaian tidak diambil kira berkenaan perkhidmatan sumber maklumat secara khusus berkenaan perpustakaan.

Jadual 1 Penilaian berdasarkan pencapaian penyelidikan

\begin{tabular}{|c|c|}
\hline Indikator & Sumber Rujukan \\
\hline Bilangan penerbitan penyelidikan & $\begin{array}{l}\text { Badri and Abdulla (2004), Manjarre's-Henrı'quez et al. (2009), Nedwek and } \\
\text { Neal (1994), Patrick and Stanley (1996) }\end{array}$ \\
\hline Bilangan projek penyelidikan & Manjarre's-Henri'quez et al. (2009) \\
\hline Bilangan paten & Kells (1992), Lukman et al. (2010), Patrick and Stanley (1996) \\
\hline Bilangan monograf & Kells (1992) \\
\hline Bilangan hasil sampingan utama daripada aliran penyelidikan & Asif et al. (2013) \\
\hline Bilangan paten yang menangani keperluan tempatan & Asif et al. (2013), Patrick and Stanley (1998) \\
\hline Peratusfakulti yang memenangi geran akademik & Kells (1992), Manjarre's-Henrı'quez et al. (2009), Patrick and Stanley (1996) \\
\hline Bilangan projek teknologi & Kells (1992), Manjarre's-Henrı'quez et al. (2009) \\
\hline Bilangan projek penyelidikan yang menangani keperluan tempatan & Asif et al. (2013), Manjarre's-Henri'quez et al. (2009) \\
\hline Peratus fakulti yang mengikuti persidangan dan seminar & Badri and Abdulla (2004), Kells (1992) \\
\hline Kesan penyelidikan & Ball and Wilkinson (1994), Lukman et al. (2010), Patrick and Stanley (1996) \\
\hline
\end{tabular}

Jadual 2 Penilaian berdasarkan pencapaian pengajaran

\begin{tabular}{ll}
\hline Indikator & Sumber Rujukan \\
\hline Kepuasan pelajar dan pihak pemegang taruh & ECPE (2011), Houston (2007), Kells(1992), Nedwek and Neal (1994) \\
& \\
Kepuasan majikan dengan kemahiran graduan & Asif and Raouf (2013), ECPE (2011), Kells (1992) \\
Bilangan pelajar yang telah tamat program & Asif and Raouf (2013), Kells (1992), Lukman et al. (2010) \\
Kadar perkembangan pelajar & Patrick and Stanley (1998) \\
Kadar keciciran (Bilangan keciciran/Bil. pelajar yang mendaftar) & Asif et al. (2013), Kells (1992) \\
Skor median pelajar & Asif et al. (2013) \\
Peratus pelajar dengan GPA tertentu & Asif et al. (2013) \\
\hline Penilaian kursus- penilaian median kursus oleh pelajar & Nedwek and Neal (1994) \\
Kadar guna tenaga pelajar & Kells (1992), Lukman et al. (2010)
\end{tabular}


Jadual 3 Penilaian berdasarkan pencapaian perkhidmatan

\begin{tabular}{ll}
\hline Indikator & Sumber Rujukan \\
\hline Bilangan rekabentuk program akademik & Asif et al. (2013) \\
Penyertaan dalam pembangunan kurikulum & Asif et al. (2013) \\
Penglibatan dalam Jawatankuasa Akademik & Kells (1992) \\
Kaunseling pelajar & Nedwek and Neal (1994) \\
Khidmat masyarakat & Badri and Abdulla (2004), ECPE (2011), Nedwek and Neal (1994) \\
\hline
\end{tabular}

Jadual 4 : Penilaian berdasarkan pencapaian kewangan

\begin{tabular}{cll}
\hline \multicolumn{2}{l}{ Indikator } & Sumber Rujukan \\
\hline Pendapatan & Kells (1992), Nedwek and Neal (1994) \\
$\begin{aligned} \text { a. } \quad \text { Pendapatan yang dijana daripada projek penyelidikan } \\
\text { b. } \quad \text { Pendapatan yang dijana daripada perundingan }\end{aligned}$ & Asif et al. (2013), Kells (1992) \\
c. $\quad$ Pendapatan yang dijana daripada hasil sampingan/ paten & Asif et al. (2013) \\
d. Penajaan/ wakaf & Asif et al. (2013), ECPE (2011) \\
e. Pendapatan yang dijana daripada tuisyen & Asif et al. (2013), ECPE (2011) \\
Perbelanjaan & Ball and Wilkinson (1994), ECPE(2011), Kells (1992), Lukman et al.(2010) \\
a. Jumlah pengajaran dan kos penyelidikan & Ball and Wilkinson (1994), ECPE (2011), Kells (1992), Lukman et al. \\
\hline
\end{tabular}

\subsection{METODOLOGI}

Kajian keratan lintang/kajian lapangan ini bertujuan menilai dan membentuk satu model pengukuran perkhidmatan perpustakaan. Ianya melibatkan penilaian tentang sejaumanakah perpustakaan berjaya memenuhi keperluan pelanggan mereka, apakah jenis-jenis penunjuk prestasi perpustakaan dalam konteks pelanggan mereka, jenis-jenis penunjuk utama prestasi perpustakaan di Malaysia dengan penunjuk di peringkat global, dan cadangan model baharu keperluan dan kepuasan pelanggan serta pencapaian perpustakaan akademik di Malaysia.

Unit analisis yang dipilih adalah individu iaitu pengguna perpustakaan dan kaedah pengumpulan data primer melalui soal-selidik digunakan sebagai alatan survei. Responden disoal bersetuju ataupun tidak bersetuju terhadap kenyataan dan mereka diminta memilih skor yang berkenaan. Soal selidik dibahagikan kepada 2 bahagian, bahagian A berkaitan demografi dan bahagian B berkaitan dengan persepsi responden terhadap kualiti perkhidmtan perpustakaan (Lihat Lampiran 1).

Skala likert digunakan sebagai unit pengukuran yang bertepatan dengan pendapat Samuel, Salkind dan rakan-rakan (2000) dan Judd, Smith dan rakan-rakan (1991) kerana skala pelbagai item sesuai diwujudkan bagi menilai sifat-sifat atau ciri ataupun persepsi individu. Tambahan pula kajian ini yang melibatkan pengukuran konsep, maka amat sesuai meggunakan kaedah pelbagai petunjuk berbanding satu petunjuk (DeVaus 1990). Begitu juga selaras dengan pendapat Vaus bahawa skala pelbagai amat baik kerana ianya amat membantu bagi situasi konsep yang kompleks, membantu mewujudkan pengukuran yang sah, membantu meningkatkan kebolehpercayaan, lebih tepat dan sesuai digunakan untuk merumuskan maklumat bagi bilangan soalan yang banyak berbanding hanya satu.

Skala jawapan dibina berdasarkan rule of measurement, iaitu panduan untuk membantu seseorang melakukan sesuatu (Zikmud 2003) di mana nilai 1 menunjukkan tahap jangkaan atau penerimaan adalah amat tidak baik, manakala 5 menunjukkan tahap jangkaan atau penerimaan amat baik. Skala disusun daripada nilai besar kepada nilai kecil. Bagi menghasilkan set soalan berstruktur yang baik, penyelidik telah merujuk, mengkaji serta menyesuaikannya daripada beberapa sumber rujukan yang utama seperti daripada tesis, artikel jurnal, piawaian, dan sebagainya. Soalan-soalan ini disusun dengan baik, kemas dan teratur supaya memudahkan responden. Penyelidik juga memastikan soal selidik memenuhi perkara-perkara seperti disediakan arahan dengan jelas, wujud jarak yang sesuai di antara soalan, dan meminimakan mukasurat supaya responden tidak jemu sepertimana dicadangkan oleh (Bell 1987).

\subsection{DAPATAN KAJIAN DAN PERBINCANGAN}

Lima ratus soal selidik telah diedarkan iaitu sebanyak 100 unit bagi setiap universiti terpilih. Hanya $76 \%$ ataupun bersamaan 381 responden telah menjawab dan memulangkannya. Jadual 5 memperincikan maklumat berkenaan. 
Jadual 5 Status pengajian

\begin{tabular}{lccccc}
\hline & Ijazah Pertama & Ijazah Lanjutan & Diploma/Sijil & Lain-lain & Jumlah (\%) \\
Kaegori Perpustakaan & 24 & 0 & 0 & 0 & $24(6.3 \%)$ \\
\hline KUIN & 88 & 0 & 7 & 0 & $95(24.9 \%)$ \\
UiTM Merbuk & 94 & 0 & 0 & 0 & $96(25.1 \%)$ \\
UiTM Arau & 96 & 0 & 2 & 3 & $69(25.9 \%)$ \\
UniMAP & 49 & 13 & & $37.6 \%)$ \\
UUM & $\mathbf{3 8 1}$ & & & $\mathbf{3 8 1}$ \\
\hline Jumlah & &
\end{tabular}

Dari segi pengalaman menggunakan perpustakaan, responden dari KUIN pernah menggunakan. Manakala bagi UiTM Merbuk dan UiTM Arau bilangan responden masing-masing menggunakan perpustakaan adalah $91.6 \%$ dan $93.8 \%$ dan UniMAP seramai $91.9 \%$ dan UUM sebanyak $97 \%$. Sementara itu dari segi bidang pengajian, di antara bidang-bidang utama adalah perkomputeran, kejuruteraan, perbankan, pemasaran, teknologi maklumat, pengurusan, sumber manusia, pendidikan, multimedia dan pengurusan perniagaan. Manakala dari segi jantina, ramai responden dari kalangan perempuan sepertimana diringkaskan dalam Jadual 6.

Jadual 6 Jantina

\begin{tabular}{llclc}
\hline Kaegori Perpustakaan & Lelaki (\%) & Perempuann (\%) & Tidak Dinyatakan & Jumlah \\
\hline KUIN & $1(4.2 \%)$ & $23(95.8 \%)$ & 0 & 1 \\
UiTM Merbuk & $30(32.7 \%)$ & $64(67.3 \%)$ & 1 & 95 \\
UiTM Arau & $31(35.7 \%)$ & $64(66.7 \%)$ & 0 & 96 \\
UniMAP & $34(34.3 \%)$ & $65(65.7 \%)$ & & 67 \\
UUM & $15(22.4 \%)$ & $52(77.6 \%)$ & & $\mathbf{3 8 1}$ \\
\hline Jumlah & & & \\
\hline
\end{tabular}

Dari segi petunjuk utama perkhidmatan perpustakaan IPT, data jangkaan pelanggan menunjukkan bagi perpustakaan KUIN, dimensi Perkhidmatan sedia digunakan /berfungsi merupakan penunjuk utama dengan skor bernilai 3.98; bgi perpustakaan UiTM Merbuk, dimensi perkhidmatan mudah diakses/dicapai pula menggambarkan penunjuk utama dengan skor purata 3.88 dan bagi perpustakaan UiTM Arau, dimensi utama ialah perkhidmatan perpustakaan bersesuaian dengan kehendak pengguna dengan nilai skor sebanyak 3.89 . Sebaliknya bagi perpustakaan UniMAP dimensinya adalah kakitangan perpustakaan cekap dalam penyediaan perkhidmatan dan untuk UUM adalah perkhidmatan sedia digunakan /berfungsi masing-masing dengan nilai skor purata 4.03 dan 4.03. Maklumat-maklumat diringkaskan seperti di Jadual 7 di bawah.

Jadual 8 pula menunjukkan penunjuk utama prestasi perkhidmatan perpustakaan untuk semua 7 dimensi perkhidmatan perpustakaan kepada 5 kategori perpustakaan yang dikaji.

Jadual 7 Petunjuk prestasi prestasi bagi setiap universiti

\begin{tabular}{|c|c|c|c|}
\hline Perpustakaan & Kategori Perkhidmatan & Purata & Susunan \\
\hline KUIN & Perkhidmatan sedia digunakan /berfungsi & 3.98 & 1 \\
\hline UiTM Merbuk & Perkhidmatan mudah diakses/dicapai & 3.88 & 1 \\
\hline UiTM Arau & Bersesuaian dengan kehendak pengguna & 3.89 & 1 \\
\hline UniMAP & Kakitangan perpustakaan cekap dalam penyediaan perkhidmatan & 4.03 & 1 \\
\hline UUM & Perkhidmatan sedia digunakan /berfungsi & 4.03 & 1 \\
\hline
\end{tabular}


Jadual 8 Petunjuk prestasi keseluruhan dimensi bagi setiap universiti

\begin{tabular}{|c|c|c|c|}
\hline Perpustakaan & Kategori Perkhidmatan & Purata & Susunan \\
\hline \multirow{7}{*}{ KUIN } & Perkhidmatan sedia digunakan /berfungsi & 3.98 & 1 \\
\hline & Perkhidmatan mudah diakses/dicapai & 3.85 & 2 \\
\hline & Kakitangan perpustakaan cekap dalam penyediaan perkhidmatan & 3.84 & 3 \\
\hline & Perkhidmatan Yan Berkesan & 3.83 & 4 \\
\hline & Bersesuaian dengan kehendak pengguna & 3.79 & 5 \\
\hline & Perkhidmatan yang boleh dipercayai & 3.76 & 6 \\
\hline & Maklumat yang betul/sah & 3.66 & 7 \\
\hline \multirow[t]{4}{*}{ Perpustakaan } & Kategori Perkhidmatan & Purata & Susunan \\
\hline & Perkhidmatan mudah diakses/dicapai & 3.88 & 1 \\
\hline & Bersesuaian dengan kehendak pengguna & 3.77 & 2 \\
\hline & Perkhidmatan sedia digunakan /berfungsi & 3.77 & 3 \\
\hline \multirow[t]{4}{*}{ UiTM Merbuk } & Perkhidmatan yang boleh dipercayai & 3.73 & 4 \\
\hline & Kakitangan perpustakaan cekap dalam penyediaan perkhidmatan & 3.71 & 5 \\
\hline & Perkhidmatan Yan Berkesan & 3.69 & 6 \\
\hline & Maklumat yang betul/sah & 3.69 & 7 \\
\hline \multirow[t]{4}{*}{ Perpustakaan } & Kategori Perkhidmatan & Purata & Susunan \\
\hline & Bersesuaian dengan kehendak pengguna & 3.89 & 1 \\
\hline & Perkhidmatan sedia digunakan /berfungsi & 3.83 & 2 \\
\hline & Maklumat yang betul/sah & 3.79 & 3 \\
\hline \multirow[t]{4}{*}{ UiTM Arau } & Kakitangan perpustakaan cekap dalam penyediaan perkhidmatan & 3.75 & 4 \\
\hline & Perkhidmatan Yan Berkesan & 3.74 & 5 \\
\hline & Perkhidmatan yang boleh dipercayai & 3.73 & 6 \\
\hline & Perkhidmatan mudah diakses/dicapai & 3.61 & 7 \\
\hline \multirow[t]{4}{*}{ Perpustakaan } & Kategori Perkhidmatan & Purata & Susunan \\
\hline & Kakitangan perpustakaan cekap dalam penyediaan perkhidmatan & 4.03 & 1 \\
\hline & Maklumat yang betul/sah & 4.01 & 2 \\
\hline & Perkhidmatan yang boleh dipercayai & 3.97 & 3 \\
\hline \multirow[t]{4}{*}{ UniMAP } & Bersesuaian dengan kehendak pengguna & 3.95 & 4 \\
\hline & Perkhidmatan sedia digunakan /berfungsi & 3.95 & 5 \\
\hline & Perkhidmatan Yang Berkesan & 3.94 & 6 \\
\hline & Perkhidmatan mudah diakses/dicapai & 3.88 & 7 \\
\hline \multirow[t]{4}{*}{ Perpustakaan } & Kategori Perkhidmatan & Purata & Susunan \\
\hline & Perkhidmatan sedia digunakan /berfungsi & 4.03 & 1 \\
\hline & Bersesuaian dengan kehendak pengguna & 4.00 & 2 \\
\hline & Perkhidmatan Yan Berkesan & 3.97 & 3 \\
\hline \multirow[t]{4}{*}{ UUM } & Perkhidmatan mudah diakses/dicapai & 3.95 & 4 \\
\hline & Kakitangan perpustakaan cekap dalam penyediaan perkhidmatan & 3.94 & 5 \\
\hline & Perkhidmatan yang boleh dipercayai & 3.91 & 6 \\
\hline & Maklumat yang betul/sah & 3.86 & 7 \\
\hline
\end{tabular}

Bagi menguji kesahan instrumen, ujian kebolehpercayaan iaitu konsistensi pengukuran dan validitasi telah digunakan. Menurut Ho (2006) kebolehpercayaan merujuk kepada ujian konsistensi dan ianya boleh diukur samada melalui ujian konsistensi luaran atau dalaman. 
Konsistensi luaran ditentukan melalui kaedah test-retest (keputusan ujian daripada suatu kumpulan responden dibandingkan dengan masa yang berlainan) dan kaedah The Equivalent Form di mana dua instrumen yang berbeza yang mempunyai kandungan yang sama dibandingkan berdasarkan analisis korelasi. Konsistensi dalaman mengukur sejauhmanakah item-item yang diuji mengukur konstruk yang sama dan penelitian konsistensi dalaman membolehkan penyelidik membuat keputusan tentang item-item yang tidak konsisten. Kajian ini memilih konsistensi dalaman sebagai kaedah pengukuran ujian kebolehpercayaan. Daripada 3 kaedah pengukuran (split-half, item analysis dan cronbach's alpha), kaedah pekali Cronbach's alpha telah yang didefinisi sebagai single correlation coefficient iaitu anggaran semua pekali keoffisen bagi setiap item yang diuji. Nilai pekali Crobanch alpha yang hampir dengan 1.0 menunjukkan tahap kebolehpercayaan amat tinggi; nilai alpha .60 menunjukkan nilai yang 'boleh diterima'; nilai alpha .70 menunjukkan skala yang 'memadai' manakala alpha .80 menunjukkan skala yang baik (Sekaran 2003; Garson 2007), manakala Ho (2005) pula mencadangkan nilai yang lebih dari 0.8.

Sepertimana dinyatakan instrumen kajian berdasarkan skala pelbagai-item. Menurut Samuel dan rakan-rakan (2000), skala ini amat sesuai digunakan bagi menilai sifat-sifat atau ciri atau persepsi individu. Hasil analisis kebolehpercayaan ditunjukkan dalam Jadual 9. Berdasarkan jadual, nilai Cronbach's Alpha adalah 0.921 dan nilai bagi ketujuh-tujuh dimensi kajian ialah di antara 0.89 hingga 0.95 bagi tahap jangkaan. Manakala bagi tahap penerimaan ialah dari 0.899 hingga 0.967 .

Jadual 9 Analisis kebolehbercayaan

\begin{tabular}{llcl}
\hline Dimensi & Bil. Item & Cronbach's Alpha \\
\hline Mudah Diakses & 7 & .921 \\
Bersesuaian & 5 & .899 \\
Sedia Digunakan & 8 & .929 & .921 \\
Berkesan & 7 & .967 & .931 \\
Cekap & 7 & .916 \\
Boleh dipercayai & 6 & 916 \\
Kesahan & 6 & \\
\hline
\end{tabular}

Menurut Ho (2005) dan Pallant (2001) lagi prosedur tambahan bagi mengukur kebolehpercayaan instrumen adalah dengan melihat nilai Corrected Item-Total Correlation (CiTC) dan Alpha if Item Deleted (AiID) iaitu seperti di Jadual 10. Berdasarkan jadual maklumat CiTC menunjukkan sejauhmana darjah hubungan setiap item atau dimensi dengan skor keseluruhan. Sekiranya nilai kurang dari 0.7 , penyelidik boleh menggugurkan item berkenaan. Manakala AiID pula menunjukkan kesan bilamana sesuatu item digugurkan. Bagi menentukan samada item berkenaan boleh ataupun tidak untuk digugurkan, nilai berkenaan dibanding dengan nilai alpha keseluruhan. Sekiranya nilai AiID melebihi daripada nilai alpha keseluruhan, penyelidik perlu menggugurkan item berkenaan. Berdasarkan maklumat-maklumat sedemikian, Instrumen Konsepsual Model Kualiti Perkhidmatan Perpustakaan mempunyai nilai konsistensi dalaman yang baik dengan nilai cronbanch's alpha 0.921 dan tidak ada nilai-nilai yang melanggari kriteria CITC dan AiID.

Jadual 10 Item total statistik

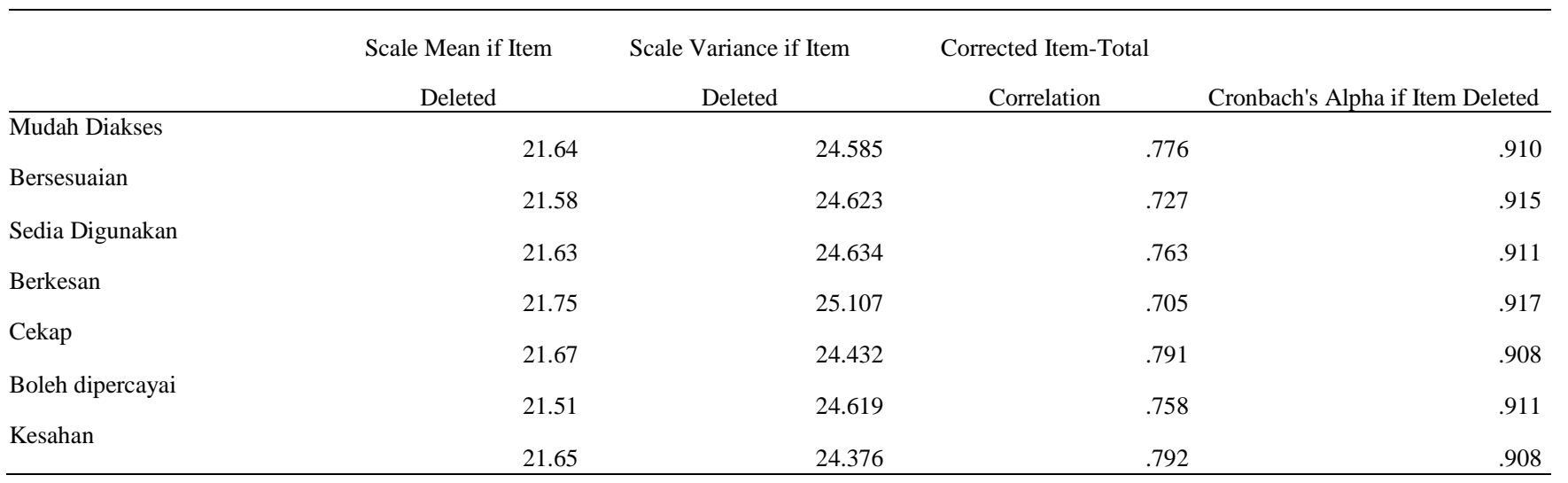

Manakala bagi mengkur kesahan kandungan, tiga ciri utama iaitu (i) persetujuan subjektif bahawa skala yang diguna menggambarkan pengukuran yang tepat tentang apa yang sepatutnya diukur (ii) kandungan tidak dapat ditentukan dengan analisis berangka kerana ia adalah subjektif dan memerlukan pertimbangan budi bicara dan (iii) ia lebih bergantung kepada bagaimana item-item berkenaan dikaitkan dan cara ia dipersembahkan telah digunakan. Kesahan kandungan instrumen dinilai berdasarkan penelitian literatur yang mendalam dan penilaian oleh para akademik sepertimana dicadangkan oleh (Terziovski \& Samson., 1999) iaitu dengan menyoal pengamal (practitioners), pertimbangan dan pendapat pakar (Cooper \& Davis, 2000; Forza, 2002). Semua komen dan cadangan telah diambil tindakan penambahbaikan. Maklumat tersebut dapat dilihat seperti di Jadual 11 (a) dan (b) di bawah. 
Jadual 11 (a) Senarai pakar dan pengamal pengurusan kualiti yang terlibat menilai soal selidik

\begin{tabular}{|c|c|c|c|c|}
\hline Bil & $\begin{array}{l}\text { Jawatan (Status } \\
\text { Responden) }\end{array}$ & Bidang Kepakaran & Institusi & Kaedah \\
\hline 1 & Pensyarah Kanan & $\begin{array}{l}\text { Sains Politik dan bekas } \\
\text { Pustakawan Kanan }\end{array}$ & Uni. Utara M'sia. & Edaran soal selidik dan perbincangan. \\
\hline 2 & Pensyarah Kanan & $\begin{array}{l}\text { Fakulti Sains Kognitif \& } \\
\text { Pendidikan }\end{array}$ & Uni. Utara M'sia. & $\begin{array}{l}\text { Edaran soal selidik dan komen dicatatkan dalam } \\
\text { soal selidik }\end{array}$ \\
\hline 3 & $\begin{array}{l}\text { Pensyarah dan } \\
\text { Timbalan Pengarah }\end{array}$ & Pengurusan Kualiti & Uni. Utara M'sia. & $\begin{array}{l}\text { Edaran soal selidik dan komen dicatatkan dalam } \\
\text { soal selidik }\end{array}$ \\
\hline 4 & Pensyarah & $\begin{array}{l}\text { Komunikasi dan Bekas } \\
\text { Pustakawan }\end{array}$ & Uni. Utara M'sia. & $\begin{array}{l}\text { Edaran soal selidik dan komen dicatatkan dalam } \\
\text { soal selidik }\end{array}$ \\
\hline 5 & Guru & Matematik dan Perpustakaan & $\begin{array}{l}\text { Institut Perguruan } \\
\text { Darulaman }\end{array}$ & $\begin{array}{l}\text { Edaran soal selidik dan komen dicatatkan dalam } \\
\text { soal selidik dan temubual }\end{array}$ \\
\hline 6 & Guru & $\begin{array}{l}\text { Teknologi Maklumat dan } \\
\text { Pegawai Pusat Sumber }\end{array}$ & $\begin{array}{l}\text { Institut Perguruan } \\
\text { Darulaman }\end{array}$ & $\begin{array}{l}\text { Edaran soal selidik dan komen dicatatkan dalam } \\
\text { soal selidik dan temubual }\end{array}$ \\
\hline
\end{tabular}

Jadual 11 (b) Jadual Komen dan cadangan penambahbaikan soal selidk daripada pakar dan pengamal kualiti

\begin{tabular}{lll}
\hline No Soalan & Komen / cadangan & Bahagian \\
\hline 5 & Untuk koleksi, bukan perkhidmatan - (12) & Set $1:$ C \\
$8,9 \& 10$ & Soalan-soalan ini sesuai untuk pelajar sahaja - (12) & Set $1:$ C \\
27 & Tidak jelas - (12) & Set $1:$ C \\
53 & Perlukan asingkan antara 'yakin' dan 'selamat' - (12) & Set $1:$ C \\
6 & Perlu tambah lagi - (14) & Set 1:C \\
NA & Ada soalan berulang dan skala 'Tidak Pasti' perlu dimasukkan (14) \& (15) & Keseluruhan \\
NA & Pembentukan soalan sesuai dengan pilihan jawapan -(15) & selidik Set 3 \\
\hline Nota : Nombor di dalam kurungan () menunjukkan responden yang memberi komen, iaitu nombor yang dicatatkan pada soalselidik
\end{tabular}

\subsection{KESIMPULAN}

Kajian ini bertujuan menguji instrumen kajian untuk digunakan sebagai model pengukuran pencapaian perpustakaan, dan sekaligus boleh digabungkan dalam model pengukuran pencapaian IPT. Ujian kebolehpercayaan telah digunakan dan hasil ujian menunjukkan instrumen kajian adalah baik. Semua dimensi mempunyai nilai alpha lebih daripada 0.7. Begitu juga perbandingan diantara 3 nilai penting apabila membincang tentang kebolehpercayaan data iaitu nilai Alpha (CA), Corrected Item-Total Correlation (CiTC) dan Alpha If Item Deleted (AiID) tiada masalah yang timbul. Oleh yang demekian konstruk ini boleh digabungkan dengan kerangka pengukuran pencapaian perpustakaan dan pengukuran pencapaian IPT.

Sebagai rumusannya, tidak seperti sektor-sektor yang lain, pencapaian perpustakaan lebih kepada pengukuran bukan berbentuk kewangan. Pengukuran juga boleh jadi bersifat subjektif ataupun objektif. Sesuai dengan peranannya, penilaian banyak difokuskan kepada kepuasan pelanggan, kecekapan dan pengurusan sumber, proses dan perkhidmatan perpustakaan. Berdasarkan kepada kajian-kajian terdahulu dan setelah dibandingkan dengan kontsruk kajian, hubungan metrik dan model pengukuran pencapaian IPT berdasarkan penilaian perkhidmatan perpustakaan dipaparkan dalam Jadual 11 di bawah..

Jadual 11 Penilaian berdasarkan perhidmatan sokongan (perpustakaan)

\begin{tabular}{|c|c|c|}
\hline Dimensi & Bil. Item & Hubungan Dimensi Pengkaji-Pengkaji Terdahulu \\
\hline Mudah Diakses & 7 & Bamigboye(2007); Brophy(2002); Hu(2001); Tser-yieth(1997); \\
\hline Bersesuaian & 5 & $\begin{array}{l}\text { Bamigboye(2007); Baroudi dan Orilowski(1988); Brophy(2002); } \quad \mathrm{Hu}(2001) \text {; } \\
\text { Tom(1992); }\end{array}$ \\
\hline Sedia Digunakan & 8 & $\begin{array}{l}\text { Beth dan Charles(1990); Brophy(2002); Hu(2001); Tom(1992); Toterdell, Gill dan } \\
\text { Hornsey(2005); Tser-yieth(1997); }\end{array}$ \\
\hline Berkesan & 7 & $\begin{array}{l}\text { Baroudi dan Orilowski(1988); Brophy(2002); Hu(2001); Tom(1992); Zaiton dan rakan- } \\
\text { rakan (1998); }\end{array}$ \\
\hline Cekap & 7 & $\begin{array}{l}\text { Bamigboye(2007); Baroudi dan Orilowski(1988); Brophy(2002); Tom(1992); Toterdell, } \\
\text { Gill dan Hornsey(2005); Zaiton dan rakan-rakan (1998); }\end{array}$ \\
\hline Boleh dipercayai & 6 & $\begin{array}{l}\text { Bamigboye(2007); Baroudi dan Orilowski(1988); Beth dan Charles(1990); } \\
\text { Brophy(2002); Hu(2001); Tom(1992); Toterdell, Gill dan Hornsey(2005); }\end{array}$ \\
\hline Kesahan & 6 & Bamigboye(2007); Baroudi dan Orilowski(1988); Hu(2001); \\
\hline
\end{tabular}


Walaupun kajian ini mengesahkan bahawa ujian kebolehpercayaan menunjukkan instrumen kajian adalah baik, namun bagi memperkukuhkan lagi instrumen, dua cadangan penambahbaikan disarankan untuk kajian lanjutan. Pertama adalah berkaitan dengan bilangan responden. Sepertimana dinyatakan di bahagian pengenalan, sehingga tahun 2013, terdapat lebih daripada satu juta enrolmen pelajar di IPT. Krejcie dan Morgan (1970) mencadangkan bahawa apabila bilangan populasi melebihi 4000, setiap pertambahan 500 responden bilangan responden ditambah satu unit ataupun bagi setiap 1000 ditambah 2 unit. Sekiranya populasi berjumlah 100,000 bilangan sampel dicadangkan adalah 384. Ini bermakna dengan jumlah pelajar satu juta, kajian akan datang ditambah bilangan responden kepada lebih daripada 1000 orang. Kedua adalah berdasarkan kaedah penilian kebolehpercayaan. Kajian ini hanya menggunakan kaedah konsistensi dalaman. Oleh iu kajian seterusnya dicadangkan supaya menggunakan kedua-dua kaedah penilaian kebolehpercayaan iaitu kebolehpercayaan dalaman dan luaran.

\section{Rujukan}

Adnan Ali Adi (2006). "Student Library Use: A Study Of Faculty Perceptions In A Malaysian University." Library Review, 55(2), 106-119.

American Library Association (2000). "Standards for College Libraries." College and Research Libraries News, (final version approved January): 175-82. Ashok Kumar Sahu (2006). "Perceptions of service Quality In An Academic Library : A Case Study." Journal of Services Research 6(1).

Asif, M. and C. Searcy (2014). "A Composite Index For Measuring Performance In Higher Education Institutions." International Journal of Quality \& Reliability Management, 31(9), 983 - 1001.

Bamigboye, O. B. (2007). "Evaluation of library Services Deilvery in Olabishi Onabanjo University, Ago-Iwoye, Nigeria." Library Management, 28(2), 152162.

Baroudi, J. and W. Orilowski (1988). "A short-Form Measure Of User Information Satisfaction." Journal of Management Information Systems, 4(4), 45-59. Bell, J. (1987). How to Complete Your Research Project Sucessfully (A Guide for First-Time Researchers). New Delhi, UBS Publishers Distributors Ltd.

Brady, M. K. and J. J. Cronin (2001). "Some New Thoughts On Conceptualizing Perceived Service Quality: A Hierarchical Approach." Journal of Marketing, $65,34-49$.

Brophy, P. (2002). EQUINOX: Library Performance Measurement And Quality Management System: Performance Indicators For Electronic Library Services. Bruce, T., C. Colleen, et al. (2003). "Two short forms of the LIBQUAL+ SURVEY : Assessing User's Perception Of Library Service Quality." The Library Quarterly, 73(4), 453-465.

Chen, T. Y. (1997). "An evaluation Of The Relative Performance Of University Libraries In Taipei." Asian Libraries. Bradford, 6(1/2), 39.

Cronin, J. J. and S. A. Taylor (1992). "Measuring Service Quality : A Re-Examination And Extension." Journal of Marketing, 56(July), 55-68.

DeVaus, D. (1990). Surveys in Social Research. London, Unwin Hyman.

Fitzgerald, L., R. Johnston, et al. (1993). Performance Measurement In Service Businesses. Cambridge, The Chartered Institute of Management Accountants. Garson, G. D. (2007). Quantitative Research in Public Administration.

Green, S. B., N. J. Salkind, et al. (2000). Using SPSS for Windows : Analyzing And Understanding Data. New Jersey, Prentice Hall.

Gronroos, C. (1984). " A service Quality Model And Its Marketing Implications." European Journal of Marketing, 18(4), 36-44.

Hu, S. C. (2001). "Establishing a new Definition For Library." Library Association of China Report 66, 1-4.

Imran, H. A. and K. Md. Zhahir (2006). Ukr tara dan Kualiti Akademik. Amalan Pengurusan dan Budaya Kualiti Institusi Pengajian Tinggi di Malaysia. K. Md. Zhahir and H. A. Imran. Bangi, Pusat Pembangunan Akademik.

International Organization for Standardization (1998(a)). International Standard - ISO 11620 : information And Documentation - Library Performance Indicators. Geneva.

Jay, K., N. Connie, et al., Eds. (2001). Service Quality management in Hospitality, Tourism, and Leisure. New York, The Haworth Hospitality Press.

Judd, C. M., E. R. Smith, et al. (1991). Research Methods in Social Relations. New York, Harcourt Brace Jovanovich College Publishers.

Kementerian Pendidikan Malaysia (2015). Indikator Pendidikan Tinggi Malaysia http://www.mohe.gov.my/web_statistik/Indikator_Pengajian_Tinggi_Malaysia_2013.pdf diakses pada 21 Julai 2015.

(KPT), K. P. T. (2002). Kod amalan jaminan kualiti Institut Pengajian Tinggi Awam Malaysia. Putra Jaya.

Krejcie, R. V. and D. W. Morgan (1970). "Determining Sample Size For Research Activities." Educational and Psychological Measurement, 30, 607-613.

Lancaster, F. W. (1993). If You Want To Evaluate Your Library. London, Library Association.

Landrum, H. T. (1999). An Analysis Of The Ability Of An Instrument To Measure Quality Of Library Service And Library Success, University of North Texas: 207.

Lawrence, W. H. T. (2000). "Quality Management Theory And Practice : Some Observations Of Practices In Australian Academic Libraries." Library Management, 21(7), 349-356.

Martensen, A. and L. Gronholdt (2003). "Improving Library Users' Perceived Quality, Satisfaction and Loyalty : An Integrated Measurement and Management System." The Journal of Academic Librarianship, 29(3), 140-147.

Md. Zhahir, K. and H. A. Imran, Eds. (2006). Amalan Pengurusan dan Budaya Kualiti Institusi Pengajian Tinggi di Malaysia. Bangi, Pusat Pembangunan Akademik.

Moris, Z., Ed. (2007). 50 Tahun Pembangunan Pendidikan Tinggi di Malaysia (1957-2007). Pulau Pinang, Penerbit Universiti Sains Malaysia.

Mustapa (2007). Masalah Siswazah Menganggur Dihapus. Utusan Malaysia. Kuala Lumpur: 1.

Nancy, A. V. H., T. W. Beth, et al. (1990). Measuring Academic Libray Performance : A Practical Approach. London, American Library Association.

Nitecki, D. A. (1995). An assessment Of The Applicability Of SERVQUAL Dimensions A Customer-Based Criteria For Evaluating Quality Of Services In An Academic Library. Faculty of the Graduate School. Ann Arbor, The University of Maryland: 280.

Nitecki, D. A. (1996). "Changing the Concept And Measure Of Service Quality In Academic Libraries." Journal of Academic Librarianship, 22(3), 181-190.

Parasuraman, A., V. A. Zeithaml, et al. (1985). "A Conceptual Model Of Service Quality And Its Implications For Future Research." Journal of Marketing, 49(Fall): 41-50.

Perkins, G. H. (2004). "Will Libraries' Web-Based Survey Methods Replace Existing Non-Electronic Survey Methods?" Journal of Information Technology and Libraries, September, 123-127.

Poll, R. (2001). "Performance, Processes And Costs: Managing Service Quality With The Balanced Scorecard." Library Trends, 49(4), 709-17.

Roslah, J. and A. N. Zainad (2007). Measuring The Library Service Performance Using SERVPERF. International Conference on Libraries, Information and Society, ICoLIS, University Malaya.

Sekaran, U. (2003). Research Methods For Business : A Skill Building Approach. United States of America, Jonh Wiley.

Singh, D. (2007). The Role of the Academic Library in Ficilitating Research : Perceptions of Postgraduate Students. International Conference on Libraries, Information and Society, ICoLIS, University Malaya, University Malaya.

Taylor, W. A. (1995). "Senior Executives And ISO 9000 : Attitudes, Behaviours And Commitment." International Journal of Quality \& Reliability Management, 12(4), 40-57.

Tom, W. (1992). "Quality in Library And Information Service: A Review." Library Management. Bradford, 13(5), 13. 
Totterdell, A., J. Gill, et al. (2005). An Introduction To Library And Information Work. London, Facet Publishing.

Walford, L. (2004). "From Trinidad to Malaysia - via Africa." Information Development 20(1).

Young, P. R. (2001). Meaningful Measures For Emerging Realities. 4th Northumbria International Conference on Performance Measurement in Libraries and Information Services, Carnegie Mellon University, Pittsburgh, PA.

Zaiton, O., G. Carole Ann, et al. (1998). "Quality services : Policies And Practices in Malaysis." Library Management, 19(1), 426-433.

Zikmud, W. G. (2003). Business Research Methods. United States of America, Thomson. 